\title{
Risks in Cold Chain Operations in Healthcare Logistics and Applicable Technological Solutions
}

\section{Sağlık Lojistiğindeki Soğuk Zincir Faaliyetlerinde Yaşanan Riskler ve Kullanılabilecek Teknolojik Çözümler}

\author{
Murat DUZGUN ${ }^{1}$ \\ Berivan KIZILIRMAK ${ }^{2}$
}

\begin{abstract}
Millions of tons of temperature-sensitive products are handled by leveraging the cold chain logistics from the point of production to the point of consumption. Cold chain, an important sub-branch of logistics, is a field which allows for the maintenance of the right quality throughout the supply chain and entails special expertise and precision for its management. The operational process becomes increasingly important in delivering products to consumers without any break in the cold chain. The pharmaceutical industry, which places human health at the forefront, includes specific products that require the cold chain logistics process, and entails special equipment and skilled staff to maintain the quality and effectiveness of such products without any break in the logistics process. Considering from the manufacturer's perspective, a potential break in the chain means loss of revenue and reputation, in other words, customer loss. The study is intended to determine the major risks that may arise in all processes related to drugs (insulins, vaccines, etc.) from the raw material to the consumer within the cold chain management, and to suggest technological and practical solutions to mitigate any potential risks and improve the existing conditions. To provide an understanding of storage conditions, particularly of solutions both at retail and customer levels, a survey was conducted with pharmacists and solution suggestions were presented with the descriptive findings assessed.
\end{abstract}

Keywords: Logistics Management, Cold Chain Logistics, Solution Technologies, Supply Chain Management, Pharmaceutical Industry

ÖZ

Sıcaklığa duyarlı milyonlarca ton ürün, üretim noktasından tüketim noktasına kadar soğuk zincir lojistiği kullanılarak gerçekleştirilmektedir. Soğuk zincir, lojistiğin önemli bir alt dalı olup, tedarik zinciri boyunca doğru kalitenin korunmasını sağlayan, yönetimi özel uzmanlık ve hassasiyet gerektiren bir alandır. Operasyonel süreç, soğuk zincirde kırılma meydana gelmeden tüketicilere ulaştırılması konusunda önem kazanmaktadır. İnsan sağlığının ön planda olduğu ilaç sektörü, soğuk zincir lojistik sürecini gerektiren ürünler içermekte ve kırılma olmaksızın kalitelerini ve etkinliklerini korumak için özel ekipman ve vasıflı personele ihtiyaç duyulan lojistik süreci gerektirmektedir. Zincirde yaşanacak kırılma, üretici açısından değerlendirildiğinde gelir ve itibar yani müşteri kayıpları anlamına gelmektedir. Çalışmada; soğuk zincir yönetiminde ilaçların (insülin, aşı vb.) hammaddeden tüketiciye gelene kadar olan tüm süreçlerinde ortaya çıkabilecek önemli riskleri tespit etmek, oluşabilecek riskleri azaltmaya ve iyileştirmeye yönelik, teknolojik çözümlerin kullanımını ve pratik çözümler önermeyi amaçlamaktadır. Depolama koşullarını, özellikle perakende ve müşteri düzeyinde olası çözümleri anlamak için eczacılar ile anket çalışması yapılmış ve betimsel bulgular değerlendirilerek çözüm önerileri sunulmuştur.

Anahtar kelimeler: Lojistik Yönetimi, Soğuk Zincir Lojistiği, Çözüm Teknolojileri, Tedarik Zinciri Yönetimi, Ilaç Sektörü

\footnotetext{
${ }^{1}$ Asst. Prof. Dr., Istanbul Medipol University, School of Business Administration and Management Sciences, mduzgun@medipol.edu.tr, ORCID: 0000-0002-8683-8925

${ }^{2}$ Lecturer, Izmir Kavram Vocation School of Higher Education, berivan.kizilirmak@ kavram.edu.tr,ORCID: 0000-0003-1153-2873
} 


\section{INTRODUCTION}

A new line of the logistics industry, the pharmaceutical cold chain logistics refers to a complex systematic project in which perishable drugs, as well as those drugs requiring a low temperature environment, are always collected in an environment with certain temperature ranges in each process before being consumed by consumers. Temperature management in cold chain logistics is key not only to the production of high-quality products, but also to the reduction of transportation waste and the cut down of transportation-storage-shipping and marketing costs. The emergence of pharmaceutical cold chain logistics, which is based on refrigeration technology, medicament and Pharmacology, has been driven by advancements in logistics and transportation. Nearly the entire transportation process of vaccine products, injections, tinctures, oral medications, drugs for external use, and blood products can be defined as pharmaceutical cold chain logistics.

Cold chain is also termed as the processes used to store, distribute, handle, transport, monitor, track and control heat-sensitive products. (Vesper, Kartoglu, Bishara, \& Reeves, 2010). Additionally, this concept refers to a whole set of procedures that encompass production, transportation, marketing and storage of frozen foods and keep all these processes under control at a given temperature (Jie, 2010).

Cold chain logistics, on the other hand, is a systematic project that not only minimizes damages or losses in all production, transportation, consumption, storage and marketing processes but also provides continuous low temperature for frozen foods which are critical in terms of quality. It is a logistics process that requires temperature adjustment relying on refrigeration technique and freezing technology. (Ma and Guan, 2009).

There is an increasing demand in the world for cold chain logistics, and this demand mostly stems from two industries. The first one is the pharmaceutical industry, and the other is the food industry. While keeping the product, either food or medicine, in the required temperature range is not enough alone in cold chain logistics, it is crucial to prevent and minimize any temperature increase or decrease reaching the set points to avoid bacterial growth, maintain the product quality and reduce product losses. Some risks, such as product losses, quality degradation, etc., happen mostly during the transportation/distribution phase (product transfer from the cold storage to transportation vehicles and vice versa). To avoid such risks, manufacturers and transporters produced some solutions such as using reefer ships, 
vehicles and containers and providing a homogeneous air flow in the vehicle during the distribution phase.

This study is intended to determine the major risks that may arise in all processes of drugs (insulins, vaccines, etc.) from the raw material to the consumer within the cold chain management, and to suggest technological and practical solutions to mitigate any potential risks and improve the existing conditions. Additionally, the literature was scanned first as part of this study in connection with the risks incurred in Health logistics and Cold Chain operations. To provide an understanding of storage conditions, particularly of solutions both at retail and customer levels, the descriptive findings of the survey with pharmacists were then assessed and the study was finalized with the conclusion and recommendations section.

\section{LITERATURE REVIEW}

Cold chain logistics is discussed by the literature in different aspects and has been frequently addressed regarding its application especially after the Covid-19 pandemic that broke out in 2019. One of the studies conducted in relation to the pandemic process is authored by Cevik (2021). Potential challenges in the production, allocation and distribution of Corona virus vaccines were investigated, based on the priority issues considered by the World Health Organization regarding the logistics of vaccines. The study's data source consisted of the earlier secondary data produced by primary research projects and the World Health Organization's guidelines and the industry reports. The study demonstrated that the greatest challenges faced during vaccination efforts were the lack of cold chain infrastructure in storage and distribution of vaccines from their production to their administration in patients, the restrictions in the aviation industry regarding transportation with dry ice and the opposition to vaccines.

In their assessment of insulin storage, Heinemann, Braune et al. (2021) remark that insulin is susceptible to changes in stability when exposed to environmental factors under storage. They state that while it is reasonable to assume that transportation conditions and temperature are good, little is known about insulin storage after dispensing when controlled during the supply chain and there is a gap in the current scientific literature with respect to insulin stability. They argue that precise dosing in diabetes treatment is important and further transparency is required on insulin stability considering this level of importance.

Bishara (2006) emphasizes that the growing importance of cold chain pharmaceutical products should be reviewed and the requirements for cold chain management, good storage 
and distribution practices, and current regulatory trends, quality management, risk assessment factors and the roles and responsibilities undertaken by temperature monitoring organizations should be fulfilled. Additionally, he remarks that it is required to monitor processes, implementation plans, timely delivery of the right product, quality measurements, continuous improvements, and customer satisfaction. He proposed suggestions for the system (Temperature monitoring system, quality management systems, etc.) that needs to be used during these processes.

Bhatnagar et al. (2018) intended to identify the challenges faced in the last mile delivery of drugs and to propose suggestions for improvement that validate international best practices. Over 100 interviews were conducted with healthcare professionals, such as doctors, pharmacists, retail pharmacy specialists, logistics partners and distributors, to have an understanding of storage conditions and likely solutions, especially on retail and customer scales. They stress that an extensive list of cold chain drugs should be in parallel with databases of hospitals, local drug distributors and drug retailers. Considering the complexity of the cold chain system, they also highlighted that the guidelines for the maintenance and management of the cold chain should be clearly available and should be followed compulsorily to avoid detrimental effects on cold chain drugs due to the issues related to storage and transportation.

The developing economic dimension of cold chain logistics and its role in two important industries for society like health and food attract an increasing attention of researchers. Shuchang, Yufan, and Radzion (2015) studied weak aspects of cold distribution chains. The first of the weak aspects is the number of transfers, followed by temperature changes during these transfers as the second weak aspect.

Using the AHP-VIKOR integrated approach, Korucuk and Erdal (2018) studied the logistics risk criteria for companies involved in cold chain logistics and the tools used by such companies to manage these risk criteria. The AHP results demonstrated that the most important logistics risk criteria is "Packaging Risks", while the results of IKOR method revealed that the optimal tool used in risk management is "Statistical Process Control".

Izer (2017) points out that the risk of breaking the refrigerated transportation chain in cold chain logistics is experienced mostly during transportation-on-transportation vehicles and when switching between vehicles and warehouses or between warehouses and aircrafts or containers. It was stated that thermal blankets, specially insulated refrigerant technologies and 
active and passive technologies are increasingly used against the risk of loss and degradation to mitigate this risk, and these new technologies were studied based on their benefits.

Choi, Chiu and Chan (2016) determined the critical risk factors in logistics systems to improve the risk management of logistics systems, listing these factors as product degradation risk, operational control risk, emergency management risk and logistics service risk.

As part of their study on drugs and practices that require special storage conditions or are subject to cold chain, Kucukturkmen and Bozkir (2018) investigated the effects of protein degradation pathways and the conditions resulting in the degradation of preparations, providing examples regarding cold chain practices and transportation and storage conditions of vaccines. It was evaluated that the loss of stability in biopharmaceutical products delivered from the point of production to pharmaceutical warehouses and from warehouses to pharmacies usually occurs during the transportation phase. In addition, they argued that the staff responsible for the cold logistics chain are not adequately trained and are not tracked by appropriate temperature monitoring devices.

Li and Chen (2011) studied the use and advantages of RFID technology in the pharmaceutical cold chain through the case of "SINOPHARM Logistics". In addition to the advantage of setting and monitoring the temperature on a real-time basis, they also stated that RFID is essential to provide the quality assurance of cold chain drugs.

There are drugs that are important for human life and subject to Cold Chain logistics. Since human life is the subject matter, the equipment used in cold chain logistics and the margin of error regarding the staff in charge of the delivery of drugs from manufacturers to consumers should be zero. Therefore, there is a lack of studies that address inventory management and cold chain from a holistic perspective among the studies conducted in the field of cold chain. It is seen that the risks associated with a single drug are evaluated, in general terms, in the cold chain logistics literature section that started to be discussed to a greater extent with the Covid-19 virus, which affected the whole world in 2020 with still ongoing effects in 2021. In line with the gap observed in the literature, this study aims to identify at which stages multiple cold chain drug products (insulins, vaccines, etc.) are exposed to the break and to propose solution technologies to contribute to time and cost analysis. 


\section{A STUDY ON PHARMACISTS AS THE STAKEHOLDERS OF PHARMACEUTICAL LOGISTICS}

The process of handling, transporting and storing drugs in an effective and efficient manner within the chain from production to consumption is called pharmaceutical logistics in the industrial sector. Differently structured from all other product logistics (Sijabat and Putri, 2018), pharmaceutical logistics plays an important role in distribution operations. Distribution operations are carried out at two levels: wholesale and retail. There are pharmaceutical warehouses operating at the wholesale distribution level as well as pharmacies operating at the retail distribution level (Tasar, 2019: 25). Additionally, pharmacists operating at the retail distribution level are liable for storing drugs in accordance with post-distribution storage conditions. Most retail pharmacies store products in non-household refrigerators. If, otherwise, drugs are stored in a household refrigerator, it causes drugs to be degraded or to lose their effect. To maintain stability and quality, refrigerators should be used under the conditions recommended by the World Health Organization (Bhatnagar et al. 2018: 36). If a refrigerator is to be used as recommended by the World Health Organization, these refrigerators should be designed so that preparations are spaced (for air circulation) and vaccines and diluting agents are widely apart from each other (Kucukturkmen and Bozkir, 2018: 310-311).

This study attempted to investigate the awareness of cold chain logistics among pharmacists who are involved in the last link of the logistics process in the pharmaceutical industry.

\subsection{Methodology}

Based on the available records for 2020, there is a total of 24,093 pharmacies registered with the Chamber of Pharmacists in Turkey: 4,912 in 39 districts of Istanbul, 1,712 in 30 districts of Izmir and 1,992 in 25 districts of Ankara. According to these figures, 36\% of pharmacies in Turkey are in 3 major metropolises: Istanbul, Izmir and Ankara. Of these 3 metropolices; Istanbul, which has the highest number of pharmacies, and Izmir, which has the ability to represent similar regions with a high number of pharmacies and a hot climate, were selected.

Since the population is spread over a very wide geography and has a very wide frame, the focus was concentrated on these two cities especially. Therefore, the sample population was developed using the purposive sampling method, which is one of the non-probabilistic 
sampling methods. The sample chosen based on the information about the characteristics of the population and the objective of the research was selected as a sample from the subgroup that was thought to represent the population and to be a typical example of the universe. The main approach; voluntary (non-probablistic) sampling methods were preferred, not probabilistic. Regarding voluntary sampling approaches, the representative method was adopted and the judgmental - purposive sampling method was specifically preferred. As samples will not be used in estimating the interval, it is not required to employ probabilistic methods.

The questionnaire includes 47 questions on the subject matter in addition to the questions on demographic information. When preparing the questionnaire, the studies by Tasar, S. I. (2019) and Kizılırmak, B. (2019) were used as references. The scale of 'Risks in Cold Chain Operations in Healthcare Logistics and Applicable Technological Solutions' comprises eight parts. The scale consists of a five-point Likert structure. The first part posed 8 questions to identify on which factors the use of cold chain logistics is effective, considering the advantages or disadvantages it offers to pharmacies. The available statements were scaled as strongly ineffective (1), ineffective (2), neither effective nor ineffective (3), effective (4) and strongly ineffective (5). The second part posed 6 questions to identify the main issues and importance levels related to the cold chain logistics infrastructure for pharmacies. The available statements were scaled as strongly unimportant (1), unimportant (2), neither important nor unimportant (3), important (4) and strongly important (5). The third part posed 10 questions to identify how often pharmacies face problems/risks when receiving cold chain logistics services. The available statements were scaled as never face (1), rarely face (2), occasionally face (3), mostly face (4) and always face (5). The fourth part posed 4 questions to identify the criteria that are important to pharmacists before using the cold chain logistics. The available statements were scaled as strongly unimportant (1), unimportant (2), neither important nor unimportant (3), important (4) and strongly important (5). The fifth part posed 8 questions to identify the performance of pharmacists after leveraging the cold chain logistics. The available statements were scaled as strongly ineffective (1), ineffective (2), neither effective nor ineffective (3), effective (4) and strongly ineffective (5). The sixth part posed 9 questions regarding the drug use and supply. The available statements were scaled in line with the responses in the form of yes- no, insulins-vaccines-certain eye drops-hormonal drugs, etc. The seventh part posed 3 questions to learn about pharmacies in general terms. The available 
statements were scaled in line with the responses in the form of yes- no, supply logisticsproduction logistics- distribution logistics, etc.

The last part asked respondents to provide certain demographic information. Some questions were asked regarding title, educational background and current employment period.

A total of 100 Pharmacies serving in various districts of Istanbul and Izmir was identified, and an equal number of equally weighted surveys (50\% Istanbul and 50\% Izmir) was submitted to them via an online link (by e-mail or message).

A total of 74 of these questionnaires, which were responded to, reached us (33 from Istanbul, 41 from Izmir) and 57 of the said questionnaires (25 from Istanbul, 32 from Izmir) were used in the survey study as they were filled out completely, free of errors. These pharmacies were specifically selected since they are centrally located (especially within a 5 $\mathrm{km}$ radius from hospitals) and are engaged in the handling and supply of cold chain products to consumers. In addition to the results, 2 Istanbul-based and 1 Izmir-based "Pharmaceutical Warehouses" handling and supplying cold chain products were asked to present their views, and the resulting findings were used in the assessment phase.

The reliability of the study was measured with Cronbach's Alpha coefficient. For this study of 57 observations, Cronbach's Alpha coefficient was calculated as $\mathbf{0 . 8 7 4}$. Cronbach's Alpha coefficient is used in reliability analyses and survey studies to see whether the questions asked to scale the same variable are consistent within themselves. The resulting

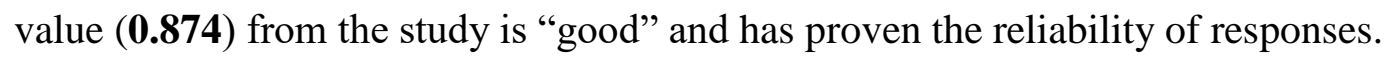

The answers of 25 subjects from Istanbul and 32 subjects from Izmir which we selected by voluntary sampling, do not contain "random error", so they are not suitable for the application (testing) of statistical principles. However, if this 57 unit subpopulation is considered (as if working with a 57 unit population), it can be evaluated with the Chi-Square Homogeneity Test whether Istanbul and İzmir answers are similar or not.

As a matter of fact, when we wanted to apply the Chi-Square Homogeneity Test to the answers and created a " $2 \times 2$ " or " $3 \times 2$ " Contencensy Table by combining rows and columns for frequencies less than " 5 " and it was concluded that the difference between 1 or 2 degrees of freedom and Istanbul also Izmir answers was not significant. Istanbul and Izmir results were combined for analysis.

The table shows the Chi-Square values and degrees of freedom calculated for some seleckted questions as follows; 


\begin{tabular}{|c|c|c|}
\hline Item Number & Degree Of Freedom & Calculated Chi-Square \\
\hline 1 & 1 & 0,69 \\
\hline 2 & 1 & 3,63 \\
\hline 3 & 1 & 0,57 \\
\hline 4 & 1 & 0,34 \\
\hline 5 & 1 & 2,10 \\
\hline 7 & 1 & 0,12 \\
\hline 19 & 2 & 1,27 \\
\hline 52 & 1 & 0,55 \\
\hline
\end{tabular}

Chi-square value 3.84 at 0.05 significance level for 1 degree of freedom;

Chi-square value 5.99 at 0.05 significance level for 2 degree of freedom;

Chi-square value 2.70 at 0.10 significance level for 1 degree of freedom;

Chi-square value 4.60 at 0.10 significance level for 2 degree of freedom was accepted.

The responses to surveys were studied on a descriptive basis and expressed in frequency and percentage.

\subsection{Findings}

Demographic information on respondents.

Table 1. Respondents

\begin{tabular}{|l|c|}
\hline \multicolumn{1}{|c|}{ Title } & \% \\
\hline Pharmacist & 52.6 \\
\hline Assistant Pharmacist & 17.5 \\
\hline Qualified Person & 10.5 \\
\hline Trainee & 19.4 \\
\hline Total & $\mathbf{1 0 0 . 0}$ \\
\hline
\end{tabular}

Given the professional titles of respondents, $52.6 \%$ of the respondents are pharmacists, $19.3 \%$ trainees $17.5 \%$ assistant pharmacists and $10.5 \%$ qualified persons as shown in Table 1 .

Table 2. Educational Background of Respondents

\begin{tabular}{|l|c|}
\hline Educational Background & $\boldsymbol{\%}$ \\
\hline High School - College & 10.5 \\
\hline School of Higher Education & 8.8 \\
\hline University & 61.4 \\
\hline Master - PhD & 19.3 \\
\hline Total & $\mathbf{1 0 0 . 0}$ \\
\hline
\end{tabular}

As the educational background of respondents is shown in Table 2, $10.5 \%$ of respondents are high school-vocational school graduates, $8.8 \%$ college graduates, $61.4 \%$ university graduates and $19.3 \%$ graduates with master's or Doctorate degree. 
Table 3. Duration of Professional Experience of Respondents

\begin{tabular}{|l|c|}
\hline Duration of Professional Experience & $\boldsymbol{\%}$ \\
\hline 0-1 year & 22.8 \\
\hline 1-3 years & 12.3 \\
\hline 3-5 years & 5.3 \\
\hline 5 years and above & 59.6 \\
\hline Total & $\mathbf{1 0 0 . 0}$ \\
\hline
\end{tabular}

Given the duration of professional experience of respondents, $59.6 \%$ of the respondents have +5 years of experience, followed by $22.8 \%$ with experience of $0-1$ year, as shown in Table 3.

Table 4. Effect of the Cold Chain Logistics on Logistics Costs, Customer Satisfaction, Response to Competitive Attacks and Level of Achievement of the Pharmacies' Goals in the Pharmaceutical Industry

\begin{tabular}{|l|c|c|c|c|}
\hline \multirow{2}{*}{ Level of Impact } & $\begin{array}{c}\text { Logistics } \\
\text { Costs }\end{array}$ & $\begin{array}{c}\text { Customer } \\
\text { Satisfaction }\end{array}$ & $\begin{array}{c}\text { Response to } \\
\text { Competitive } \\
\text { Attacks }\end{array}$ & $\begin{array}{c}\text { Level of } \\
\text { Achievement of the } \\
\text { Pharmacies' Goals }\end{array}$ \\
\cline { 2 - 5 } Strongly Ineffective & $\mathbf{\%}$ & $\mathbf{\%}$ & $\mathbf{\%}$ & \% \\
\hline Ineffective & 5.3 & 3.5 & 7.5 & 3.5 \\
\hline $\begin{array}{l}\text { Neither Effective } \\
\text { Nor Ineffective }\end{array}$ & 10.5 & 8.8 & 26.4 & 10.5 \\
\hline Effective & 56.1 & 56.1 & 52.6 & 36.8 \\
\hline Strongly Effective & 24.6 & 29.8 & 10.5 & 49.2 \\
\hline Total & $\mathbf{1 0 0 . 0}$ & $\mathbf{1 0 0 . 0}$ & $\mathbf{1 0 0 . 0}$ & $\mathbf{1 0 0 . 0}$ \\
\hline
\end{tabular}

The value calculated according to the Chi-Square Analysis (according to 2 degrees of freedom) between the "Response to Competitive Attacks" and "Level of Achievement of the Pharmacies' Goals" profiles was found to be 16.56. Accordingly, "Level of Achievement of the Pharmacies' Goals" stands out from the others in the table 4 above.

This section of the survey attempted to reach the views of respondents on cold chain logistics. Considering their views on the "Effect of the Cold Chain Logistics on Logistics Costs and Customer Satisfaction", $85.9 \%$ of the respondents remarked that it is effective as indicated in Table 4. Given its effect on logistics costs, the effective conditions can be listed as use of proper technological equipment, proper transportation, and qualified staff. Additionally, the occurrence of all elements acting on logistics costs has a direct impact on 
customer satisfaction. Considering the respondents' views on the "Effect of the Cold Chain Logistics on Response to Competitive Attacks and Level of Achievement of the Pharmacies' Goals", $52.6 \%$ of the respondents selected the answer 'effective' regarding 'response to competitive attacks' and $89.5 \%$ selected the answer 'strongly effective' regarding 'level of achievement of pharmacies' goals.

The proper use of equipment in the cold chain avoids the circumstances such as break in a chain or degradation of drugs. If pharmacies use cold chain storage products (vaccine, blood and IV drip storage cabinets...) properly, they respond to competitive attacks by attaining customer satisfaction and have the edge over others in achieving the pharmacy's goals.

Table 5. Effect of the Cold Chain Logistics on Employee Performance, Flexibility, Loss Rate and Labor Savings in the Pharmaceutical Industry

\begin{tabular}{|l|c|c|c|c|}
\hline \multirow{2}{*}{ Level of } & $\begin{array}{c}\text { Employee } \\
\text { Performance }\end{array}$ & Flexibility & Loss Rate & $\begin{array}{c}\text { Labor } \\
\text { Savings }\end{array}$ \\
\cline { 2 - 5 } & $\boldsymbol{\%}$ & $\%$ & $\%$ & $\%$ \\
\hline $\begin{array}{l}\text { Strongly } \\
\text { Ineffective }\end{array}$ & 3.5 & 3.0 & 1.8 & 2.8 \\
\hline Ineffective & 8.8 & 7.0 & 1.8 & 10.5 \\
\hline $\begin{array}{l}\text { Neither Effective } \\
\text { Nor Ineffective }\end{array}$ & 14.0 & 27.6 & 12.3 & 24.1 \\
\hline Effective & 54.4 & 39.3 & 54.4 & 46.1 \\
\hline $\begin{array}{l}\text { Strongly } \\
\text { Effective }\end{array}$ & 19.3 & 23.1 & 29.7 & 16.5 \\
\hline Total & $\mathbf{1 0 0 . 0}$ & $\mathbf{1 0 0 . 0}$ & $\mathbf{1 0 0 . 0}$ & $\mathbf{1 0 0 . 0}$ \\
\hline
\end{tabular}

When the respondents were asked to present their views on the "Effect of the Cold Chain Logistics on Employee Performance and Flexibility", 54.4\% of the respondents remarked that it is effective on 'employee performance', followed by $39.3 \%$ who indicate that it is effective on 'flexibility', as provided in Table 5. Using the proper technological equipment in cold chain logistics facilitates the job of employees. Employees who achieve the minimum error level reflect this in their performance. When the respondents' view on the "Effect of the Cold Chain Logistics on Loss Rate and Labor Savings" are reviewed, 'loss rate' was effective at $54.4 \%$ and 'labor saving' at $46.1 \%$ as provided in Table 5. Given the circumstances listed for logistics costs in Table 4, these will directly reduce the loss rate within the business and minimize the costs. Using technological tools that are mentioned in the study has a positive impact on labor savings. 
This section of the survey attempted to reach the views of respondents on the fundamental issues and their level of importance regarding the cold chain logistics. Considering their views on "Failure to Deliver on Time and Damaged-Short Delivery in the Cold Chain Logistics", $50.9 \%$ of the respondents regarded 'failure to deliver on time' very important, preceded by $64.9 \%$ who considered 'damaged/short delivery' to be very important, as provided in Table 6 .

Table 6. Importance Level of Failure to Deliver on Time, Damaged-Short Delivery, High Transportation Costs, High Warehouse/Bonded Warehouse Costs, Lack of Knowledgeable and Experienced Staff and Transport Infrastructure for Pharmacies in the Pharmaceutical Industry

\begin{tabular}{|c|c|c|c|c|c|c|}
\hline $\begin{array}{l}\text { Importance } \\
\text { Level }\end{array}$ & $\begin{array}{l}\text { Failure } \\
\text { to } \\
\text { Deliver } \\
\text { on } \\
\text { Time } \\
\end{array}$ & $\begin{array}{l}\text { Damaged- } \\
\text { Short } \\
\text { Delivery }\end{array}$ & $\begin{array}{l}\text { High } \\
\text { Transportation } \\
\text { Costs }\end{array}$ & $\begin{array}{l}\text { High } \\
\text { Warehouse/Bonded } \\
\text { Warehouse Costs }\end{array}$ & $\begin{array}{l}\text { Lack of } \\
\text { Knowledgeable } \\
\text { and } \\
\text { Experienced } \\
\text { Staff }\end{array}$ & $\begin{array}{l}\text { Transportation } \\
\text { Infrastructure }\end{array}$ \\
\hline & $\%$ & $\%$ & $\%$ & $\%$ & $\%$ & $\%$ \\
\hline $\begin{array}{l}\text { Strongly } \\
\text { Unimportant }\end{array}$ & - & - & 1.5 & 1.8 & 1.8 & 0.0 \\
\hline Unimportant & 1.7 & 3.5 & 7.0 & 3.5 & 5.0 & 1.8 \\
\hline $\begin{array}{l}\text { Neither } \\
\text { Important } \\
\text { nor } \\
\text { Unimportant }\end{array}$ & 5.3 & 3.5 & 10.0 & 12.2 & 5.0 & 7.0 \\
\hline Important & 42.1 & 28.1 & 31.0 & 50.9 & 47.5 & 50.9 \\
\hline $\begin{array}{l}\text { Very } \\
\text { Important }\end{array}$ & 50.9 & 64.9 & 50.5 & 31.6 & 40.7 & 40.3 \\
\hline Total & 100.0 & 100.0 & 100.0 & 100.0 & 100.0 & 100.0 \\
\hline
\end{tabular}

Chi-square value calculated between columns 1 and 2 of Table 6 is 2.303 (degree of freedom $=1$ ) Chi-square value calculated between columns 4, 5 and 6 of Table 6 is 3.15 (degree of freedom $=4$ ) Chi-square value calculated between columns 2 and 4 of Table 6 is 12.95 (degree of freedom $=2$ ) Chi-square value calculated between the 3rd and 5th columns of Table 6 is 3.88 (degree of freedom $=2$ )

According to these results, the $1^{\text {st }}, 2^{\text {nd }}$ and $3^{\text {rd }}$ columns of the table 6 are similar. Especially the $1^{\text {st }}$ and $2^{\text {nd }}$ columns are separated from the others.

In addition to the failure to timely deliver cold chain products, the non-use of refrigerated vehicles, temperature-controlled containers, protective foam guards and gel packs leads to not only breaks in the cold chain, but also to damaged-short deliveries. When the respondents' view on the "High Transportation Costs and Warehouse/Bonded Warehouse Costs in the Cold Chain Logistics" are reviewed, 50.5\% of the respondents replied that 'high transportation costs' are very important and 50.9\% replied that 'high warehouse/bonded warehouse costs' are important, as provided in Table 6. Any vehicles used in cold chain transportation should be equipped with a technological infrastructure. High purchasing costs of these vehicles are also reflected in transportation costs. 
Products are stored at special warehouses to avoid any break in the cold chain process at warehouses/bonded warehouses. As it is difficult and costly to provide certain special equipment (such as vaccine, blood and IV drip storage cabinets, transfer cabinets, vaccine vial monitors, cold water or ice batteries) used at warehouses/bonded warehouses, this has a direct effect on warehouse/bonded warehouse costs. Considering the views of respondents on "Lack of Knowledgeable and Experienced Staff and Transportation Infrastructure in the Cold Chain Logistics", $47.5 \%$ of the respondents replied that 'lack of knowledgeable and experienced staff' is important and $50.9 \%$ replied that 'transportation infrastructure' is important, as provided in the relevant table. Cold chain products are the products that require further attention than other products in the transportation phase. Additionally, knowledgeable, and experienced staff are required for these products.

The staff involved in all links of the cold chain from transportation to distribution should undergo special training. The limited number of such staff or their lack of knowledge prepares the ground for breaks in the cold chain and the resulting issues induced by this break.

Table 7. Frequency of Events Experienced During the Cold Chain Logistics Services in the Pharmaceutical Industry (1)

\begin{tabular}{|l|c|c|c|c|c|}
\hline \multirow{2}{*}{$\begin{array}{c}\text { Frequency of Various } \\
\text { Issues }\end{array}$} & $\begin{array}{c}\text { Failure to } \\
\text { Deliver } \\
\text { Drugs on } \\
\text { Time }\end{array}$ & $\begin{array}{c}\text { Damaged } \\
\text { Drugs }\end{array}$ & $\begin{array}{c}\text { Failure to } \\
\text { Comply with } \\
\text { Contractual } \\
\text { Terms }\end{array}$ & $\begin{array}{c}\text { Broken Cold } \\
\text { Chain }\end{array}$ & $\begin{array}{c}\text { Purchasing } \\
\text { Risks }\end{array}$ \\
\cline { 2 - 6 } & $\boldsymbol{\%}$ & \% & \% & \% & \% \\
\hline Never Experience & 3.5 & 14.0 & 42.1 & 37.5 & 14.0 \\
\hline Rarely Experience & 33.3 & 45.6 & 38.6 & 40.7 & 35.1 \\
\hline Occasionally Experience & 61.4 & 35.1 & 17.5 & 19.0 & 40.4 \\
\hline Frequently Experience & 1.8 & 5.3 & 1.8 & 2.8 & 10.5 \\
\hline Total & $\mathbf{1 0 0 . 0}$ & $\mathbf{1 0 0 . 0}$ & $\mathbf{1 0 0 . 0}$ & $\mathbf{1 0 0 . 0}$ & $\mathbf{1 0 0 . 0}$ \\
\hline
\end{tabular}

This section of the survey attempted to reach the views of respondents to identify which problems/risks they faced and how often when receiving the cold chain logistics service. Considering the respondents' view on 'Failure to Timely Deliver Drugs and Damaged Drugs in the Cold Chain Logistics", as provided in Table 7, 61.4\% of the respondents replied that they occasionally face the problem of 'failure to timely deliver drugs' and $45.6 \%$ replied that they rarely face the problem of 'damaged drugs', as provided in Table 7. In addition to the failure to timely deliver cold chain products, the non-use of necessary 
special equipment was reported to cause breaks in the cold chain (Table 6). The vast majority of the respondents involved in the survey remarked that they occasionally face this problem. As a general judgment, the tools given in Table 6 are utilized, and the staff act meticulously. As demonstrated by all these replies, the majority of pharmacies stated that they rarely face the problem of damaged drugs. When the views of respondents on "Failure to Comply with Contractual Terms and Broken Cold Chain in the Cold Chain Logistics" are reviewed, 42.1\% of the respondents replied that they never face the problem of 'failure to comply with contractual terms' and $40.7 \%$ replied that they rarely face the problem of 'broken cold chain', as provided in Table 7. Based on the question we posed to pharmacists in Table 22, the existence of formal agreements and long-term commitments with suppliers directly affects compliance with the contractual terms. The replies indicating the existence of knowledgeable and experienced staff using the proper equipment in the process from the transportation to the distribution stage of the cold chain are seen in common. The vast majority of pharmacists rarely face the problem of broken cold chain.

Table 8. Frequency of Events Experienced During the Cold Chain Logistics Services in the Pharmaceutical Industry (2)

\begin{tabular}{|l|c|c|c|c|c|}
\hline \multirow{2}{*}{ Frequency of Issues } & $\begin{array}{c}\text { Inadequate } \\
\text { Infrastruct } \\
\text { ure }\end{array}$ & $\begin{array}{c}\text { Inaccurate } \\
\text { Delivery }\end{array}$ & $\begin{array}{c}\text { Transportation- } \\
\text { Induced Risks }\end{array}$ & $\begin{array}{c}\text { Risks Arising } \\
\text { from } \\
\text { Information } \\
\text { Flow }\end{array}$ & $\begin{array}{c}\text { Packaging } \\
\text { Risks }\end{array}$ \\
\cline { 2 - 6 } & $\mathbf{\%}$ & $\mathbf{\%}$ & $\mathbf{\%}$ & $\mathbf{\%}$ & $\mathbf{\%}$ \\
\hline Never Face & 24.6 & 15.7 & 15.8 & 15.8 & 21.1 \\
\hline Rarely Experience & 47.4 & 57.9 & 45.6 & 42.1 & 50.8 \\
\hline $\begin{array}{l}\text { Occasionally } \\
\text { Experience }\end{array}$ & 22.8 & 24.6 & 35.1 & 31.6 & 21.1 \\
\hline $\begin{array}{l}\text { Frequently } \\
\text { Experience }\end{array}$ & 5.3 & 1.8 & 3.5 & 10.5 & 1.8 \\
\hline Total & $\mathbf{1 0 0 . 0}$ & $\mathbf{1 0 0 . 0}$ & $\mathbf{1 0 0 . 0}$ & $\mathbf{1 0 0 . 0}$ & $\mathbf{1 0 0 . 0}$ \\
\hline
\end{tabular}

When the respondents' view on 'Inadequate Infrastructure and Inaccurate Delivery in the Cold Chain Logistics" are reviewed, $47.4 \%$ of the respondents replied that they rarely face the problem of 'inadequate infrastructure' and $15.7 \%$ replied that they never face the problem of 'inaccurate delivery', as provided in Table 8. While the required technology and tools for infrastructure are costly, we can note from the replies provided that there are companies that follow and put into practice these developments in the industry. The majority of respondents stated that they rarely face the problem of inadequate infrastructure. Facing this issue rarely had a further positive effect on inaccurate deliveries. Again, the majority of respondents 
indicated that they rarely face the problem of inaccurate delivery. Considering the views of respondents on "Transportation-Induced Risks and Risks Arising from Information Flow in the Cold Chain Logistics", $45.6 \%$ of the respondents replied that they rarely face the problem of 'transportation-induced risks' and $42.1 \%$ replied that they rarely face the 'risks arising from information flow', as provided in Table 8 . Table 6 refers to the underlying positive effects of the rare encounter with transportation-induced risks. The risks arising from information flow may be reviewed under the topic of communications and transportation infrastructure. The replies provided indicated that a robust transportation and equipment infrastructure also applies to the field of communications and transportation. Additionally, long-term contracts and mutual agreements had a positive effect on this. As provided in Table 8, 50.8\% of the respondents replied that they rarely face the problem of 'packaging risks' and $10.5 \%$ replied that they frequently face the problem of 'purchasing risks. The delivery and distribution of cold chain drugs in their original packaging is crucial to the shelf life of drugs. It is a key aspect that should be considered in the purchasing phase.

Table 9. Key Criteria for Pharmacists Before Using the Cold Chain Logistics in the Pharmaceutical Industry (1)

\begin{tabular}{|l|c|c|c|c|}
\hline \multirow{2}{*}{ Importance Level } & $\begin{array}{c}\text { Material } \\
\text { Handling } \\
\text { Capacity }\end{array}$ & $\begin{array}{c}\text { Customer Services } \\
\text { and Reliability }\end{array}$ & $\begin{array}{c}\text { Location of } \\
\text { Head Office and } \\
\text { Branches of the } \\
\text { Transportation } \\
\text { Company }\end{array}$ & $\begin{array}{c}\text { Innovation } \\
\text { and } \\
\text { Efficiency } \\
\text { of Cold } \\
\text { Chain } \\
\text { Operations }\end{array}$ \\
\cline { 2 - 5 } & $\boldsymbol{\%}$ & $\mathbf{\%}$ & $\mathbf{\%}$ & \% \\
\hline Unimportant & 3.5 & 2.5 & 10.5 & 1.8 \\
\hline Neither Important nor & 28.1 & 6.5 & 12.3 & 8.8 \\
\hline Unimportant & 54.4 & 35.3 & 54.4 & 52.6 \\
\hline Very Important & 14.0 & 55.7 & 22.8 & 36.8 \\
\hline Total & $\mathbf{1 0 0 . 0}$ & $\mathbf{1 0 0 . 0}$ & $\mathbf{1 0 0 . 0}$ & $\mathbf{1 0 0 . 0}$ \\
\hline
\end{tabular}

This section of the survey sought the views of respondents as to what criteria exist before the respondents use the cold chain logistics. When the views of respondents on "Material Handling Capacity and Customer Services and Reliability in the Cold Chain Logistics" are reviewed, $54.4 \%$ of the respondents replied that 'material handling capacity' is important and $55.7 \%$ replied that 'customer services and reliability' is very important, as provided in Table 9. Keeping up with technology and using the special equipment necessary for the cold chain 
allows for the performance of the handling phase in a rapid and reliable way. Rapidity and quality will directly have a further positive effect on customer satisfaction and reliability. The respondents took advantage of this positive effect. When the respondents were asked to present their views on the "Location of Head Office and Branches of the Transportation Company and Innovation and Efficiency of Cold Chain Operations in the Cold Chain Logistics", $54.4 \%$ of the respondents replied that the 'location of head office and branches of the transportation company' are important and 52.6\% replied that 'innovation and efficiency of cold chain operations' is important, as provided in Table 9. While specific equipment is used in the cold chain, such as refrigerated vehicles and temperature-controlled containers, the proximity of the transportation company to the points of distribution is a key aspect in terms of customer satisfaction and transportation costs. This is demonstrated by the replies provided by pharmacists.

This section aims to identify the performance of pharmacists after leveraging the cold chain logistics.

Table 10. Performance Values for Pharmacists Using the Cold Chain Logistics in the Pharmaceutical Industry (1)

\begin{tabular}{|l|c|c|c|c|}
\hline \multirow{2}{*}{ Level of Effect } & $\begin{array}{c}\text { Drug } \\
\text { Costs }\end{array}$ & $\begin{array}{c}\text { Range of } \\
\text { Manufactured } \\
\text { Pharmaceutical } \\
\text { Products }\end{array}$ & $\begin{array}{c}\text { Drug } \\
\text { Substitution } \\
\text { Time }\end{array}$ & $\begin{array}{c}\text { On-Time } \\
\text { Delivery }\end{array}$ \\
\cline { 2 - 5 } & $\boldsymbol{\%}$ & $\mathbf{\%}$ & $\mathbf{\%}$ & $\boldsymbol{\%}$ \\
\hline Strongly Ineffective & 5.3 & 3.5 & 1.8 & 0.0 \\
\hline Ineffective & 8.8 & 8.8 & 3.5 & 0.0 \\
\hline $\begin{array}{l}\text { Neither Effective Nor } \\
\text { Ineffective }\end{array}$ & 8.8 & 7.0 & 10.5 & 3.5 \\
\hline Effective & 47.4 & 49.1 & 50.9 & 49.1 \\
\hline Strongly Effective & 29.8 & 31.6 & 33.3 & 47.4 \\
\hline Total & $\mathbf{1 0 0 . 0}$ & $\mathbf{1 0 0 . 0}$ & $\mathbf{1 0 0 . 0}$ & $\mathbf{1 0 0 . 0}$ \\
\hline
\end{tabular}

This section of the survey sought the views of respondents on their performance after using the cold chain logistics. When the respondents were asked to present their views on the "Effect of the Cold Chain Logistics on Drug Costs and Range of Manufactured Products", the cold chain logistics was found to be $47.4 \%$ effective on 'drug costs' and $49.1 \%$ effective on the 'range of manufactured pharmaceutical products', as provided in Table 10. When transportation, storage and distribution in the cold chain is handled using the necessary 
equipment and knowledgeable and experienced staff, no drugs are exposed to degradation. This is also reflected in drug costs positively. In addition, this is supported by the replies provided in the table. Specific drugs that require cold chain cannot be produced due to the lack of proper transportation conditions and necessary infrastructure. Any aspects with a positive effect on Drug Costs also affect the range of manufactured pharmaceutical drugs positively. When the respondents were asked to present their views on the "Effect of the Cold Chain Logistics on Drug Substitution Time and On-Time Delivery", the cold chain logistics was found to be $50.9 \%$ effective on 'drug substitution time' and $49.1 \%$ effective on 'on-time delivery', as provided in Table 10. The favorable location of the head office and branches of the company engaged in cold chain transportation positively affects the drug substitution time and on-time delivery performance.

Table 11. Performance Values for Pharmacists Using the Cold Chain Logistics in the Pharmaceutical Industry (2)

\begin{tabular}{|l|c|c|c|c|}
\hline \multirow{2}{*}{ Level of Effect } & $\begin{array}{c}\text { Customer } \\
\text { Satisfaction }\end{array}$ & $\begin{array}{c}\text { Inventory } \\
\text { Costs }\end{array}$ & $\begin{array}{c}\text { Prevention of } \\
\text { Transportation- } \\
\text { Induced Risks }\end{array}$ & $\begin{array}{c}\text { Reduction of } \\
\text { Breaks in } \\
\text { the Cold } \\
\text { Chain }\end{array}$ \\
\cline { 2 - 5 } & $\%$ & $\%$ & $\%$ & $\%$ \\
\hline $\begin{array}{l}\text { Strongly } \\
\text { Ineffective }\end{array}$ & 0.0 & 0.0 & 0.0 & 0.0 \\
\hline Ineffective & 0.0 & 1.8 & 3.5 & 1.8 \\
\hline $\begin{array}{l}\text { Neither } \\
\text { Effective Nor } \\
\text { Ineffective }\end{array}$ & 1.8 & 7.0 & 3.5 & 8.8 \\
\hline Effective & 38.6 & 52.6 & 59.6 & 55.5 \\
\hline $\begin{array}{l}\text { Strongly } \\
\text { Effective }\end{array}$ & 59.6 & 38.6 & 33.3 & 33.9 \\
\hline Total & $\mathbf{1 0 0 . 0}$ & $\mathbf{1 0 0 . 0}$ & $\mathbf{1 0 0 . 0}$ & $\mathbf{1 0 0 . 0}$ \\
\hline
\end{tabular}

When the respondents were asked to present their views on the "Effect of the Cold Chain Logistics on Customer Satisfaction and Inventory Costs", 59.6\% of the respondents stated that it is strongly effective on 'customer satisfaction' and 52.6\% remarked that it is effective on 'inventory costs', as provided in Table 11. When the respondents were asked to present their views on the "Effect of the Cold Chain Logistics on the Prevention of Transportation-Induced Risks and Reduction of Breaks in the Cold Chain", 59.6\% of the respondents stated that it is effective on the 'prevention of transportation-induced risks', followed by $55.5 \%$ who 
indicated that it is effective on the 'reduction of breaks in the cold chain', as provided in Table 11.

The questions below are related to the drug use and supply by pharmacies.

Table 12. Use Rate for Pharmaceutical Track and Trace System in the Pharmaceutical Industry

\begin{tabular}{|l|c|}
\hline \multicolumn{1}{|c|}{ PTTS Use } & \% \\
\hline No & 7.0 \\
\hline Yes & 93.0 \\
\hline
\end{tabular}

When the respondents were asked to present their views on the use of "Pharmaceutical Track and Trace System in the Cold Chain Logistics', it was found that 93\% of the respondents use the pharmaceutical track and trace system as provided in Table 12. Using the pharmaceutical track and trace system, pharmacists can easily identify counterfeit drugs and mitigate the adverse consequences of this situation for human health and the resulting damage to the economy. Additionally, the pharmaceutical track and trace system makes the recall process easier and better in case of an issue with the manufacturing of drugs.

Table 13. Availability Rate for Prescription Drugs in the Pharmaceutical Industry

\begin{tabular}{|l|c|}
\hline Availability of Prescription Drugs & \% \\
\hline Yes & 50.9 \\
\hline No & 0.0 \\
\hline Occasionally problematic & 49.1 \\
\hline Total & $\mathbf{1 0 0 . 0}$ \\
\hline
\end{tabular}

When the respondents were asked to present their views on "Availability Rates for Prescription Drugs in the Cold Chain Logistics", 50.9\% of the respondents remarked that they had no difficulty in making prescription drugs available to their patients as provided in Table 13. The central location of cold chain drug warehouses brings benefits to pharmacists. Any drug that is not available in the pharmacy is delivered to the patient in a short span of period, and nearly all cold chain drugs can be easily stored as warehouses/bonded warehouses have the necessary infrastructure. 
Table 14. Category of Drugs Challenging for Pharmacists to Supply in the Pharmaceutical Industry

\begin{tabular}{|l|c|}
\hline \multicolumn{1}{|c|}{ Drugs Challenging to Supply } & $\%$ \\
\hline Prescription drugs & 10.5 \\
\hline $\begin{array}{l}\text { Prescription drugs, non-prescription drugs, } \\
\text { foreign drugs on demand }\end{array}$ & 10.5 \\
\hline Prescription drugs, foreign drugs on demand & 17.5 \\
\hline Non-prescription drugs & 7.0 \\
\hline $\begin{array}{l}\text { Non-prescription drugs, foreign drugs on } \\
\text { demand }\end{array}$ & 14.0 \\
\hline Foreign drugs on demand & 40.4 \\
\hline Total & $\mathbf{1 0 0 . 0}$ \\
\hline
\end{tabular}

When the respondents were asked to present their views on the "Category of Drugs Challenging for Them to Supply in the Cold Chain Logistics", $40.4 \%$ of the respondents reportedly had difficulties in supplying any foreign drugs on demand as provided in Table 14. There are certain types of drugs that need to be requested from abroad. Any issues with the supply times of these drugs negatively affect pharmacists and most importantly, patients. Since human life is the subject matter, such circumstances can be resolved in minimum time by air transportation.

Table 15 provides the list of replies received when the respondents were asked to present their views on "Problems with the Supply of Prescription Drugs in the Cold Chain Logistics".

Table 15. Problems with the Supply of Prescription Drugs in the Pharmaceutical Industry

\begin{tabular}{|c|c|}
\hline $\begin{array}{c}\text { Difficulty in Prescription Drugs } \\
\text { Supply }\end{array}$ & $\%$ \\
\hline $\begin{array}{l}\text { Unavailability of drugs at } \\
\text { pharmaceutical warehouses }\end{array}$ & 72.4 \\
\hline $\begin{array}{l}\text { Problems with the distribution of } \\
\text { drugs }\end{array}$ & 12.0 \\
\hline $\begin{array}{l}\text { Recall of the relevant drug by } \\
\text { companies }\end{array}$ & 15.6 \\
\hline Total & 100.0 \\
\hline
\end{tabular}

The most common problems include unavailability of drugs at pharmaceutical warehouses by $72.4 \%$, problems in the drug distribution phase by $12.3 \%$ and recall of various drugs, which manufacturers are asked to supply, by $19.3 \%$. 
Table 16. Most Common Cold Chain Products Available at Pharmacies in the Pharmaceutical Industry

\begin{tabular}{|l|c|}
\hline Cold Chain Products & $\boldsymbol{\%}$ \\
\hline Insulins & 66.7 \\
\hline Vaccines & 14.0 \\
\hline Specific eye drops & 10.5 \\
\hline Hormonal drugs & 8.8 \\
\hline Total & $\mathbf{1 0 0 . 0}$ \\
\hline
\end{tabular}

When the respondents were asked to provide their views on the "Most Common Cold Chain Products Available at Pharmacies in the Cold Chain Logistics", they reported that the most frequently used cold chain product was insulin drugs by $66.7 \%$ as provided in Table 16 . One of the most important cold chain drugs, insulins are among the most popular and demanded cold chain drugs at pharmacies.

Table 17. Most Common Problems with Prescription Cold Chain Products in the Pharmaceutical Industry

\begin{tabular}{|l|c|}
\hline \multicolumn{1}{|c|}{ Problems with Cold Chain Products } & \% \\
\hline $\begin{array}{l}\text { Incapacity of the supplier to supply drugs to } \\
\text { pharmaceutical warehouses }\end{array}$ & 66.7 \\
\hline Inability of patients to reach drugs at any time & 19.3 \\
\hline $\begin{array}{l}\text { Limited inventory time at pharmaceutical } \\
\text { warehouses }\end{array}$ & 14.0 \\
\hline Total & $\mathbf{1 0 0 . 0}$ \\
\hline
\end{tabular}

When the respondents were asked to present their views on "Most Common Problems with Prescription Cold Chain Products in the Pharmaceutical Industry', the answer is the 'incapacity of manufacturers to supply drugs to pharmaceutical warehouses' $(66.7 \%)$ as provided in Table 17. The pharmacists who had difficulties, although rarely, in obtaining prescription cold chain products reported that this was mainly caused by the manufacturer's failure to supply drugs to pharmaceutical warehouses. As understood from the results of the study, pharmacists do not face problems with cold chain transportation to a large extent. In this case, the underlying reasons for the manufacturer's failure to provide drugs to pharmaceutical warehouses can be investigated separately. 
Table 18. Packaging Methods Preferred by Pharmacists for Cold Chain or Other Pharmaceutical Groups in the Pharmaceutical Industry

\begin{tabular}{|l|c|}
\hline \multicolumn{1}{|c|}{ Packaging Method } & \% \\
\hline $\begin{array}{l}\text { Drug-specific boxing method (avoiding } \\
\text { breaks in the cold chain or deformation } \\
\text { of drug boxes) }\end{array}$ & 78.5 \\
\hline $\begin{array}{l}\text { Method of transporting drugs in } \\
\text { cardboard boxes }\end{array}$ & 13.0 \\
\hline Bagging method & 8.5 \\
\hline Total & $\mathbf{1 0 0 . 0}$ \\
\hline
\end{tabular}

When the respondents were asked to present their views on "Packaging Methods Preferred by Pharmacists for Cold Chain or Other Pharmaceutical Groups in the Pharmaceutical Industry", they remarked that the most preferred packaging method is the 'drug-specific boxing method (which avoids breaks in the cold chain or deformation of drug boxes - 78.5\%) as provided in Table 18. Transportation companies and pharmacists use various equipment not to break the cold chain during the process of cold chain product transportation to their distribution. Pharmacists opt for the proper packaging of drugs in line with the type of drugs (using foam guards, gel packs, vaccine and blood transfusion containers, ice packs, styrofoam cardboard boxes and foam boxes).

Table 19. Packaging Methods Preferred by Suppliers at the Stage of Delivery of Supplied Cold Chain Products to Pharmacies in the Pharmaceutical Industry

\begin{tabular}{|l|c|}
\hline \multicolumn{1}{|c|}{ Packaging Method } & $\%$ \\
\hline Ice batteries, refrigerated bags & 33.3 \\
\hline Refrigerated gel packs and others & 10.5 \\
\hline $\begin{array}{l}\text { Styrofoam cardboard boxes and } \\
\text { others }\end{array}$ & 15.8 \\
\hline Styrofoam and others & 40.4 \\
\hline Total & $\mathbf{1 0 0 . 0}$ \\
\hline
\end{tabular}

When the respondents were asked to present their views on the "Packaging Methods Preferred by Suppliers at the Stage of Delivery of Supplied Cold Chain Products to Pharmacies in the Pharmaceutical Industry', 40.4\% of the respondents replied 'styrofoam packaging technique' as provided in Table 19. Favorable locations of warehouses enable products to be transported in styrofoam protectors. Additionally, styrofoam protectors meet 
the packaging requirements (drug-specific boxing method which avoids avoiding breaks in the cold chain or deformation of drug boxes) sought by pharmacists.

General information on the pharmacies involved in the survey are given in the following tables.

Table 20. Rate of Outsourcing in Cold Chain Logistics Operations in the Pharmaceutical Industry

\begin{tabular}{|c|c|}
\hline Outsourcing & $\%$ \\
\hline Yes & 35.0 \\
\hline No & 65.0 \\
\hline
\end{tabular}

When the respondents were asked to present their views on the "Rate of Outsourcing in Cold Chain Logistics Operations in the Pharmaceutical Industry', 65 of the respondents stated that they avoid using outsourcing as provided in Table 20. It is indispensable for pharmacies to use outsourcing in the cold chain. On the other hand, there are some pharmacists who supply drugs from the warehouse using their own means, albeit in small numbers. There is a need for the infrastructure and experienced and knowledgeable staff, namely external resources, at the transportation and supply stage of cold chain drugs.

Table 21. Areas of Outsourcing in the Pharmaceutical Industry

\begin{tabular}{|l|c|}
\hline \multicolumn{1}{|c|}{ Areas of Outsourcing } & \% \\
\hline Supply Logistics & 43.9 \\
\hline Production Logistics & 5.3 \\
\hline Distribution Logistics & 26.3 \\
\hline Supply Logistics, Distribution Logistics & 19.3 \\
\hline Supply Logistics, Production Logistics & 5.3 \\
\hline Total & $\mathbf{1 0 0 . 0}$ \\
\hline
\end{tabular}

When the respondents were asked to present their views on "Areas of Outsourcing in the Cold Chain Logistics", $43.9 \%$ of the respondents stated that they use supply logistics, 5.3\% production logistics, $26.3 \%$ distribution logistics, 19.3\% supply and distribution logistics and $5.3 \%$ supply and production logistics as provided in Table 21. 
Table 22. Types of Agreements Between Pharmacists and Contracted Suppliers for Outsourcing Services in the Pharmaceutical Industry

\begin{tabular}{|l|c|}
\hline \multicolumn{1}{|c|}{ Type of Agreement } & \% \\
\hline $\begin{array}{l}\text { All logistics operations are carried out by } \\
\text { the supplier. }\end{array}$ & 31.6 \\
\hline $\begin{array}{l}\text { The required logistics service is contracted } \\
\text { to the appropriate supplier on the market } \\
\text { for once. }\end{array}$ & 7.0 \\
\hline $\begin{array}{l}\text { The job is contracted to the same supplier } \\
\text { when required, but job specifications are } \\
\text { not discussed every time. }\end{array}$ & \\
\hline $\begin{array}{l}\text { Formal agreements and mutual } \\
\text { commitments }\end{array}$ & 17.5 \\
\hline Total & $\mathbf{1 0 0 . 0}$ \\
\hline
\end{tabular}

When the respondents were asked to present their views on "Types of Agreements Between Pharmacists and Contracted Suppliers for Outsourcing Services in the Cold Chain Logistics", $43.9 \%$ of the respondents were found to handle outsourcing services in accordance with formal agreements and mutual commitments as provided in Table 22. Most of the pharmacists conduct business in line with formal agreements and mutual commitments during the outsourcing phase. Pharmacists who execute an agreement based on this form of service are rarely exposed to circumstances such as non-compliance with contractual terms, additional costs, and failure to deliver on time.

Based on the replies provided by pharmacy employees, nearly $60 \%$ of whom have 5 years or more experience, the resulting general structure was found to be as provided below:

-Cold chain logistics costs and customer satisfaction are key to the ability to respond to competitive attacks,

-Timely and complete delivery is crucial to the transportation infrastructure,

-The most common issues include inaccurate delivery, transportation and packaging risks and failure to provide information flow,

-Taking advantage of the cold chain affects the pharmacy's performance in some respects, such as drug costs, product type, substitution time and on-time delivery,

-Increased customer satisfaction and reduced inventory costs are effective on avoidance of transportation risks, 
-There are some particular problems within the supply of drugs from abroad, and the inability of drug manufacturers to supply drugs to warehouses results in further problems,

-Pharmacies opt for packaging products that prevent breaks in the cold chain, such as special boxes, ice batteries and styrofoam,

-About $60 \%$ of pharmacies that receive outsourced services make use of this type of service on a contractual basis, if deemed necessary.

\section{CONCLUSION AND SUGGESTIONS}

In the light of the findings of the survey with Pharmacy employees (pharmacists, assistant pharmacists, qualified persons and trainees), who are the last chain of the cold chain logistics process, the cold chain logistics has two core components: Human to store and distribute cold chain products (1) and equipment to be used in the distribution and storage of products (2). Where these two components are not used properly, breaks in the cold chain arise from changes in product temperature, mistakes before pre-cooling, deficiencies regarding air freshening, transportation time, mode of transportation, problems with unrefrigerated time, improper packaging, mistakes during storage and preparation, quality management, personnel management, retail sales problems, failure to use and/or misuse of the necessary equipment for the cooling system (Kirbas, 2019: 10-11).

The risks associated with product losses, quality deterioration, etc. occur at the stages of transportation/distribution, insufficient infrastructure, lack of packaging procedures and inaccurate outsourcing. To avoid such risks, manufacturers and transporters produced some solutions such as using reefer ships, vehicles and containers and providing a homogeneous air flow in the vehicle during the distribution phase. In addition, they get support from the everadvancing technology (vial temperature monitors, WSN, RFID, 1G-RFID, 2G-RFID, IoT, ITS, DataMatrix and 2D Barcode, etc.). Thus, manufacturers avoid losses and have the opportunity to reach more markets, reducing the quality and product degradation rate in the product transportation and transfer process. Additionally, they should exercise due diligence regarding the transportation and packaging of the products used in the cold chain logistics by special logistics tools and the location of the existing cold chain warehouses at a favorable point.

In addition, reefer vehicles, temperature-controlled containers and vaccine, blood and IV drip storage containers and protective foam guards, cold water or ice batteries, gel packs 
and shake-flask tests are among the key equipment of the cold chain link, and manufacturers and pharmacists should use such equipment properly. While the pharmacists involved in the study had less often problems with infrastructure, cold chain equipment, transportation and communication, technology should be followed closely for the innovation and effectiveness of cold chain processes, and the staff working in the cold chain link should be provided with training accordingly.

The proposed solutions, which this study attempted to explain briefly, are presented to hospital staff, especially to pharmacists who play an important role in delivering cold chain drugs to consumers/patients, and to people with the responsibility for storing, retailing and distributing such drugs. It would bring great benefits to follow the advancing technology and to maintain research projects that study the importance of transfer and transportation in the cold chain and the risks arising at these stages. In addition, technologies intended to reduce carbon emissions, vehicle routing problems and warehouse management solutions are current issues that can be discussed within the scope of cold chain.

\section{REFERENCES}

Aksoy, T. (2012). Tokat İl Merkezindeki Eczanelerde Soğuk Zincir Uygulamalarının İncelenmesi. Gaziosmanpaşa Üniversitesi Sağlık Bilimleri Enstitüsü, Tokat.

Bhatnagar, A. Gupta, V. Tandon, P. Saksena, T. Ranjan, A. Gandhi, P. Shilpa, C. G. \& Kapoor, A. (2018). Last mile delivery of cold chain medicines-challenges and recommendations. Indian Journal of Pharmaceutical and Biological Research, 6(01), $34-41$.

Balachandran, K. (2019). Cold Chain And İnsulin: Should We Follow The Polio Vaccine Example? Indian Journal Of Endocrinology And Metabolism, 23(3), 379-379.

Chikumba, P. (2009). Application Of Geographic İnformation System (GIS) In Drug Logistics Management Information System (LMIS) At District Level In Malawi: Opportunities And Challenges. In International Conference On E-Infrastructure And E-Services For Developing Countries (Pp. 105-115). Springer, Berlin, Heidelberg.

Choi, T. M. Chiu, C. H. \& Chan, H. K. (2016). Risk Management Of Logistics Systems. Transportation Research Part E: Logistics And Transportation Review, Elsevier, Volume 90, Pages 1-6.

Emanet, S. (2018). Türkiye'de Üretilen Soğuk Zincir İlaçların Lojistik Faaliyetlerinin İyileştirilmesi Üzerine Bir Çalışma. Okan Üniversitesi Sosyal Bilimler Enstitüsü, İstanbul. 
Günaydın, T. (2016). Sağlık Malzemleri-İlaç Lojistiği, Okan Üniversitesi, İstanbul. Erişim Tarihi: 15.03.2021, https://pt.slideshare.net/gunaydintugay

Heinemann, L. Braune, K. Carter, A. Zayani, A. \& Krämer, L. A. (2021). Insulin Storage: A Critical Reappraisal. Journal Of Diabetes Science And Technology, 15(1), 147159.ydn. doi: 10.1177/1932296819900258

İlaç Takip Sistemi (İTS) Portal1, (2019). İlaç takip sistemi. Erişim tarihi: 18.02.2021, https://www.its.gov.tr/its/ilac_takip_sistemi_nedir\#ProjeTanimi

İzer, D. A. (2017). Soğuk Zincir Lojistiği İçinde Risklerin Azaltılmasında Yeni Teknolojiler.

Jie, L. (2010). Issues Of Food-Related Cold-Chain Logistics Management In China. In 2010 International Conference on Logistics Systems and Intelligent Management (ICLSIM) (pp. 1319-1322). IEEE. doi: 10.1109/ ICLSIM.2010.5461178

Kırbaş, A. S. (2019). Tam Otomatik Çift Kompresörlü Akıllı Aşı ve İlaç Dolabı Tasarımı. Bursa Uludağ Üniversitesi Fen Bilimleri Enstitüsü, Bursa.

Kızılırmak, B. (2019). Uluslararası Şirketlerde Dış Kaynak Kullanımı ve Lojistik Anlayış; Sivas Özelinde Bir Uygulama. Cumhuriyet Üniversitesi İktisadi ve İdari Bilimler Dergisi, 20(1), 447-461.

Küçüktürkmen, B., \& Bozkır, A. (2018). Özel Saklama Koşulu Gerektiren veya Soğuk Zincire Tabi İlaçlar Ve Uygulamalar Açısından Değerlendirmeler. Ankara Üniversitesi Eczacılık Fakültesi Farmasötik Teknoloji Anabilim Dalı, 75(3), 305-322.

Kolutek, R. (2017). Aş1lar. Erişim Tarihi: 18.02.2021, https://slideplayer.biz.tr/slide/

Korucuk, S.\& Erdal, H. (2018). AHP-VIKOR Bütünleşik Yaklaşımıyla Lojistik Risk Faktörlerinin ve Risk Yönetimi Araçlarının Sıralanması: Samsun İli Örneği. Isşletme Araştırmaları Dergisi, 10(3 S 282305).

Li, F.\& Chen, Z. (2011). Brief Analysis Of Application Of RFID İn Pharmaceutical ColdChain Temperature Monitoring System. In Proceedings 2011 International Conference On Transportation, Mechanical, And Electrical En. doi: $\underline{10.1109 \text { / }}$ TMEE.2011.6199709

Lu, S. Gu, Y. \& Predko, R. (2015). How To Assess Risks In Weak Links In Cold Chain Distribution Process? Gineering (TMEE) (pp. 2418-2420). IEEE.

Ma, G. \& Guan, H. (2009). The Application Research Of Cold-Chain Logistics Delivery Schedule Based On JIT. In 2009 International Conference on Industrial Mechatronics and Automation (pp. 368-370). IEEE.

Monteleone, S. Sampaio, M. \& Maia, R. F. (2017). A novel Deployment Of Smart Cold Chain System Using 2G-RFID-Sys Temperature Monitoring In Medicine Cold Chain Based On Internet Of Things. In 2017 IEEE International Conference on Service Operations and Logistics, and Informatics (SOLI) (pp. 205-210). IEEE. doi: 10.1109 / $\underline{\text { SOLI.2017.8120995 }}$ 
Ooi, D. (2008). Insulin Access İn The Developing World: Problems And Solutions. Diabetes Intl, 8, 5. Liverpool School of Tropical Medicine, Liverpool, UK.

Pezzuto, J. M., Johnson, M. E., Manasse, H. R. (2013). Biotechnology and Pharmacy. Berlin, Almanya: Springer Science \& Business Media

Sijabat, R. \& Putri, T. W. S. (2018). Review of the Logistics Process in the Pharmaceutical Sector. Retrieved from http://e-journal.uajy.ac.id/14649/1/JURNAL.pdf

Shafaat, K. Hussain, A. Kumar, B. Ul Hasan, R. Prabhat, P. \& Yadav, V. K. (2013). An Overview: Storage Of Pharmaceutical Products. World Journal Of Pharmacy And Pharmaceutical Sclences, 2(5), 2499-515. ISSN 2278 - 4357

Taşar, S. İ. (2019). Ankara İlinde Çalışan Eczacıların İlaç Temininde Yaşanan Sorunlar Konusunda Görüşleri: Anket Çalışması. Çankaya Üniversitesi Sosyal Bilimler Enstitüsü, Çankaya.

Taylor, J. (2001). Recommendations On The Control And Monitoring Of Storage and Transportation Temperatures Of Medicinal Products. The Pharmaceutical Al Journal, 267(28), 128-131.

T.C. Ulaştırma Bakanlığı (2006). Ulusal Kamu Araştırma Programı. Erişim tarihi: 22.02.202, https://docplayer.biz.tr/1342940-T-c-ulastirma-bakanligi-ulusal-ulastirma-kamuarastirma-programi.html

Torun, S. D. (2006). Ümraniye Eğitim Ve Araştırma Sağlık Grup Başkanlığı Bölgesinde Aş1lama Hizmetleri Ve Soğuk Zincir Yönetimi Üzerine Eğitimin Etkisi. Marmara Üniversitesi Sağlık Bilimleri Enstitüsü, İstanbul.

Türk Eczacıları Birliği. (29.12.2020). Aşılar Hakkında Bilinmesi Gerekenler. Erişim tarihi: 05.03.2021, https://www.zeo.org.tr/haber-5067

Vesper, J., Kartoğlu, Ü., Bishara, R. \& Reeves, T. (2010). A Case Study In Experiential Learning: Pharmaceutical Cold Chain Management On Wheels. Journal of Continuing Education in the Health Professions, 30(4), 229-236. doi:10.1002/chp.20087

WHO; 2007. (2007). In-Depth Evaluation Of Reaching Every District Approach In The Africanregion.

Zhang, D. \& Han, T. (2020). Analysis Of Risk Control Factors Of Medical Cold Chain Logistics Based On ISM model. In 2020 Chinese Control And Decision Conference $(C C D C)$ (pp. 4222-4227). IEEE. doi: 10.1109/CCDC49329.2020.9164042

https://webcache.googleusercontent.com/search?q=cache:1BHQydkshLEJ:https://www.titck.g ov.tr/PortalAdmin/Uploads/UnitPageAttachment/c1cfd8dc10483.pdf $+\& \mathrm{~cd}=1 \& \mathrm{hl}=\mathrm{tr}$ $\underline{\mathrm{ct}=\mathrm{clnk} \& \mathrm{gl}=\mathrm{tr}}$ 